\title{
Symmetric basal ganglia calcification in a 9-year-old child with MELAS
}

\author{
Sheng-Horng Chung, MD; Shyr-Chyr Chen, MD; \\ Wen-Jone Chen, MD, PhD; and Chien-Chang Lee, MD, MSc
}

$\Delta$ 9-year-old boy presented with headache, vomiting, and leftward eye gaze deviation. On examination, left homonymous hemianopia, horizontal nystagmus, and anisocoric pupils were noted. Brain CT disclosed symmetric calcification in basal ganglia (figure A). Blood examination showed lactic academia. Further MRI revealed right occipito-temporo-parietal cortical hyperintensities (figure, B and C). Muscle biopsy revealed raggedred fibers, and genetic study showed an A3243G point mutation, confirming the diagnosis of mitochondrial encephalomyopathy, lactic acidosis, and strokelike symptoms (MELAS). Symmetric basal ganglia calcification, focal cerebral lesions not confined to the vascular territories in a young patient warrant further workup for mitochondrial cytopathy.,2

\section{References}

1. Valanne L, Ketonen L, Majander A, Suomalainen A, Pihko H. Neuroradiologic findings in children with mitochondrial disorders. Am J Neuroradiol 1998;19:369-377.

2. Sue CM, Crimmins DS, Soo YS, et al. Neuroradiological features of six kindreds with MELAS tRNA (Leu) A2343G point mutation: implications for pathogenesis. J Neurol Neurosurg Psychiatry 1998;65:233-240.
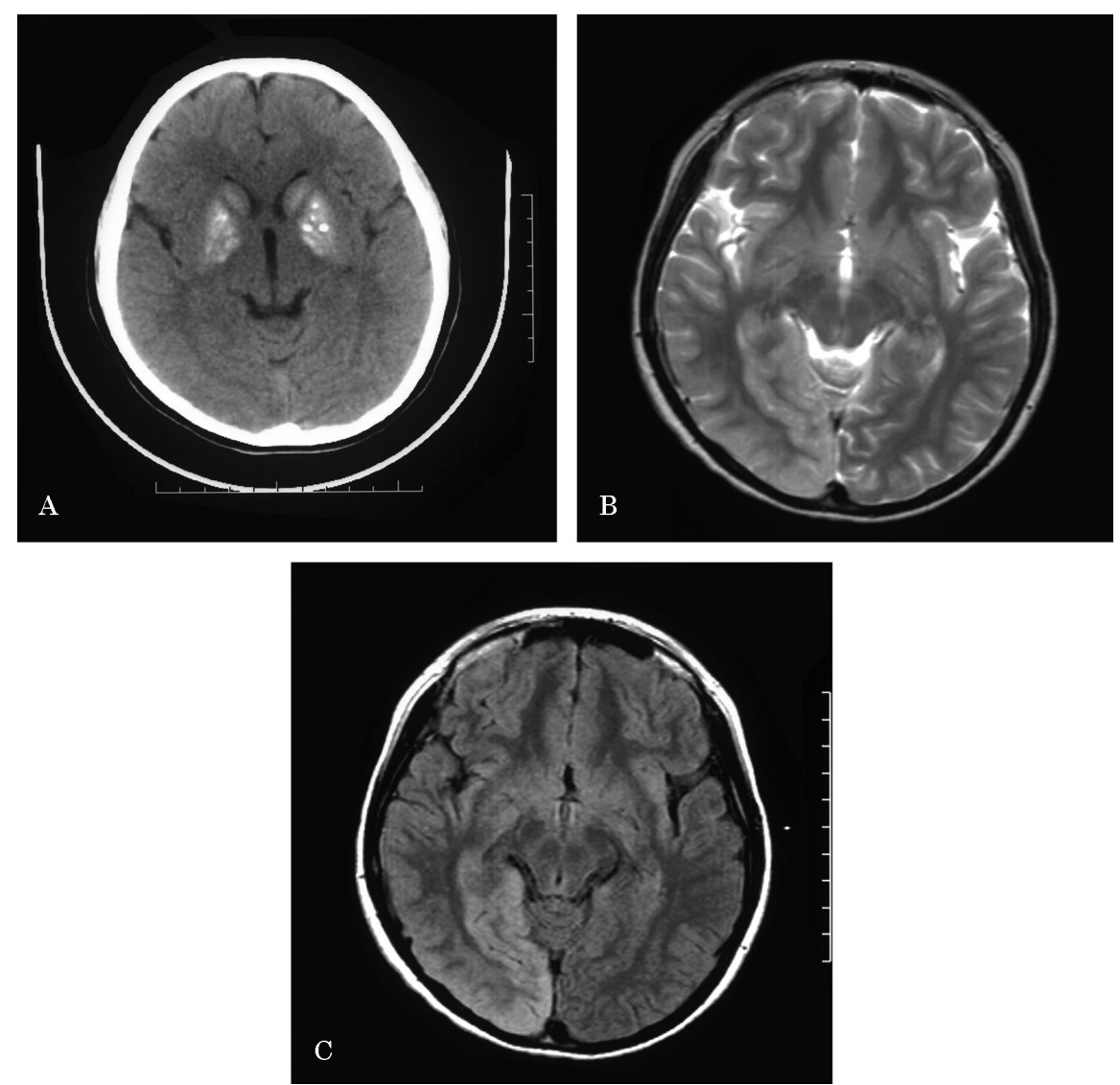

Figure. (A) CT image of brain shows symmetric bilateral hyperintensities in bilateral putamen, globus pallidus, and caudate head. (B) T2-weighted axial MRI shows areas of hyperintensities over peripheral parenchyma of right occipital, temporal, and parietal lobes. (C) Axial fluid-attenuated inversion recovery MRI shows right occipital, temporal, and parietal peripheral parenchyma hyperintensities, which do not correlate with vascular territories. 


\section{Neurology}

\section{Symmetric basal ganglia calcification in a 9-year-old child with MELAS}

Sheng-Horng Chung, Shyr-Chyr Chen, Wen-Jone Chen, et al.

Neurology 2005;65;E19

DOI 10.1212/01.wnl.0000184112.34211.d1

\section{This information is current as of November 7, 2005}

\section{Updated Information \&}

Services

Supplementary Material

References

Subspecialty Collections

Permissions \& Licensing

Reprints including high resolution figures, can be found at: http://n.neurology.org/content/65/9/E19.full

Supplementary material can be found at: http://n.neurology.org/content/suppl/2007/04/02/65.9.E19.DC1

This article cites 2 articles, 1 of which you can access for free at: http://n.neurology.org/content/65/9/E19.full\#ref-list-1

This article, along with others on similar topics, appears in the following collection(s):

Basal ganglia

http://n.neurology.org/cgi/collection/basal_ganglia

Mitochondrial disorders

http://n.neurology.org/cgi/collection/mitochondrial_disorders

MRI

http://n.neurology.org/cgi/collection/mri

Information about reproducing this article in parts (figures,tables) or in its entirety can be found online at:

http://www.neurology.org/about/about_the_journal\#permissions

Information about ordering reprints can be found online: http://n.neurology.org/subscribers/advertise

Neurology ${ }^{\circledR}$ is the official journal of the American Academy of Neurology. Published continuously since 1951, it is now a weekly with 48 issues per year. Copyright . All rights reserved. Print ISSN: 0028-3878. Online ISSN: 1526-632X.

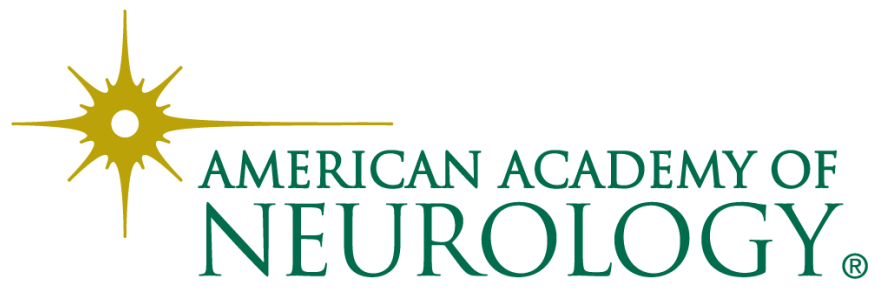

